ELORE (ISSN 1456-3010), vol. 18 - 2/2011.

Julkaisija: Suomen Kansantietouden Tutkijain Seura ry.

[http://www.elore.fi/arkisto/2_11/soderholm.pdf]

KIRJA-ARVIO

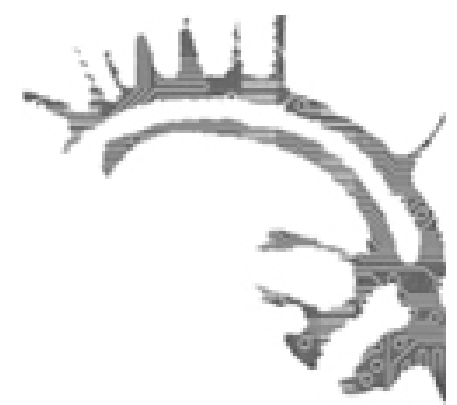

\title{
FANIKULTTUURIEN TUTKIMUKSEN MAHDOLLISUUKSIA
}

NIKUNEN, KAARINA (toim.) 2008: Fanikirja - tutkimuksia nykykulttuurin faniilmiöistä. Nykykulttuurin tutkimusyksikön julkaisuja 96. Jyväskylän yliopisto.

$\underline{\text { Stig Söderholm }}$

Kaarina Nikusen toimittama fanitutkimuksen antologia täydentää tyylikkäästi vuonna 2003 ilmestyneen Kulttikirjan (toim. Urpo Kovala ja Tuija Saresma) tematiikkaa. Vuosikymmenen kuluessa fani-ilmiöiden ja fandom-yhteisöllisyyden tutkimisesta onkin tullut selkeästi osa kulttuurintutkimuksen valtavirtaa. Fani-ilmiöiden ja niiden teollisen tuottamisen kiihtyvä arsenaali pitää huolta siitä, että tutkijat löytävät aineistonsa; nykyään ongelmana onkin lähinnä se, löydetäänkö aineistoihin vielä uusia kiinnostavia kulmia ja kysymyksiä.

Tietyllä tavalla Fanikirjan kirjoitusten tematiikassa kertautuvat suomalaisen ja laajemminkin angloamerikkalaisen populaarikulttuurin tutkimuksen ajalliset kerrokset: rockmusiikin ja sen käytön tutkimus (Päivi-Tuulikki Hynysen artikkeli Ismo Alangon fanikirjeistä), mediakulttuurin tutkimus (Kaarina Nikusen, Eeva Haverisen ja Riikka Turtiaisen artikkelit), nuoriso- ja tyttötutkimuksen traditio (Helena Saarikosken kirjoitus varhaisnuorten Spice Girls -leikeistä), ja edellä mainittujen ohella ja lisäksi vielä yleisö/kuluttaja -kulmasta avautuvia kirjoituksia.

Mikäli Fanikirjan tarjonnasta haluaa hakea jotain spesiaalipainotusta, niin se liittyy lähinnä uskonnollisten kokemusten ja faniuden problematisointiin. Tätä tematiikkkaa käsittelevät Irma Hirsjärvi, joka kirjoittaa suomalaisten scifi-fanien uskonnollisiin kokemuksiin viittaavista puhetavoista. Teemu Tairan "Fanius ja uskonto" tarjoaa puolestaan kiinnostavia argumentteja. Taira nostaa tarkastelunsa keskiöön implisiittisen uskonnon käsitteen, jolla hän viittaa lähinnä brittiläisen tutkimuksen virtauksiin. Sinänsä kiinnostavaa huomata, että Jacques Waardenburgin vuosikymmeniä sitten tekemä, hermeneuttiseen teoriaan pohjaava eronteko implisiittisen (uskonto intentionaalisena tekemisenä) ja eksplisiittisen (uskonto institutionaalisena ja semanttisesti nimettynä toimijana) uskonnollisuuden välillä löytää uuden kontekstinsa populaarikulttuurin teorioissa. Ylisummaanhan uskonto-käsitteen tuomista fani-ilmiöitä selittäväksi tai 
Stig Söderholm: Fanikulttuurien tutkimuksen mahdollisuuksia

luonnehtivaksi tekijäksi on toisinaan kritisoitu (esim. Lawrence Grossberg) populaarikulttuurin tutkimuksen piirissä. Taira puolestaan hakee, nähdäkseni aivan vakuuttavasti, uskonnon läsnäoloa populaarikulttuurin ilmiömaailmassa, yhtäältä rituaalisen käyttäytymisen ja toisaalta myöhäismodernististen "hetkellisten yhteisöllisyyksien" kautta.

Kirjan päättää Urpo Kovalan erinomainen ja keskusteluun haastava pohdinta faniuden ja fanitutkimuksen historiallisuuden ja kontekstisidonnaisuuden vaikutuksista fanitutkimuksen hahmotuksiin. Kovala ei varsinaisesti allekirjoita "maffesolilais-baumannilaisen löyhän yhteisöllisyyden" oletuksia fandomeja mahdollistavana aktuaalisena asiantilana; sen sijaan hän suuntaa katsetta ja ajattelua olemassa oleviin ja todellisiin kulttuurisiin eroihin fandomien ehdollistajina. Metodisesti kyse on jo muutamaan kertaan unohdetuksi tuomitun menetelmän, siis vertailun, henkiin herättämisestä: "Vertailu on tehokas tapa nostaa esiin fandomin ja skenen kontekstien piirteitä, joita muuten on vaikea havaita." Huomautus on tähdellinen jo siksikin, että se antaa tutkijalle tietynlaisen legitimiteetin määrittää fani- ja populaarikulttuuristen ilmiöiden olemusta ilman sitoutumista kulttuurin toimijoiden ja tai toimijoiden konstruoiman skenen omiin puhetapoihin.

Suomalaisen kulttuurintutkimuksen vähittäisessä muotoutumisessa Fanikirja asettuu jatkumolle, jonka ajallisesti etäinen alkupiste löytyy - tutkimuksen piirissä nyt jo kulttikirjan statuksen saavuttaneesta - vuonna 1975 ilmestyneestä kirjasta Aika on aikaa (toim. Seppo Knuuttila). Kyseisessä teoksessa julkaistu Matti Kuusen artikkeli "Johdatus idolianalyysiin", jonka kirjoittaja varovaisesti määritti (1970-luvulla populaarikulttuurin akateemiseen tutkimiseen suhtauduttiin totaalisesti toisin kuin nykyään) luonnosmaiseksi johdatukseksi uuteen tutkimusalueeseen, on itse asiassa ehtinyt toimia enemmän tai vähemmän tiedostettuna suuntavilkkuna jo useammalle tutkijasukupolvelle. Esimerkiksi Urpo Kovalan toteamus, "että sekä synkroninen että diakroninen vertailuasetelma voivat tarjota hyödyllistä vastavalotusta sekä täsmentää faniuden kuvausta ja tulkintaa” (s. 237) on perusnäkemykseltään hyvinkin sopusoinnussa edellä mainitun Matti Kuusen idoli-pohdinnan kanssa; kulttuurintutkimuksen myötä Kuusen hahmottelemasta idolien tyypittelystä on sïrrytty fanisuhteiden problematisointiin. Vaikka puhtaasti fenomenologisella tasolla fanikulttuurin käyttäytymismuodot saattavat olla jokseenkin yleisiä ja yhtäläisiä USA:ssa, Japanissa, Intiassa ja Euroopassa, niin talouksien ja muiden kontekstien erilaisuudet tuottavat väistämättä erilaisuutta populaarikulttuurin käyttöön ja merkitysten tuottamiseen; tällaisen asetelman tutkimuksellinen haltuunotto edellyttää myös vertailevan tarkastelukulman käyttämistä.

\section{KirjallisuUs}

KNUUTTILA, SEPPO (toim.) 1975: Aika on aikaa...: Tutkielmia poploresta. 2. painos. Helsinki: Gaudeamus.

KOVALA, URPO \& SARESMA, TUIJA (toim.) 2003: Kulttikirja: tutkimuksia nykyajan kultti-ilmiöistä. Helsinki: SKS.

Dosentti, FT Stig Söderholm toimii kulttuuriantropologian yliopistonlehtorina Itä-Suomen yliopistossa. 